measurements were made on the fresh rock samples at room temperature and pressure.

The results of these determinations and the stratigraphic level above basal (red) Chalk are shown graphically in Fig. 1. At the bottom of the section the velocity of compressional waves reaches almost $5 \mathrm{~km}$. $/ \mathrm{sec}$., while at the top it is a little more than $3 \mathrm{~km}$./sec. The velocity changes linearly with depth and the velocity gradient is about $5 \mathrm{sec}^{-1}$. These velocities are considerably greater than those given for Chalk in the south of England, but can be matched in north-west Germany ${ }^{3}$. There is no mention of an appreciable velocity gradient in the Chalk of southern England, and even in north-west Germany the value is less than 2 sec. $^{-1}$.

A fuller account of this, together with related work, will be published elsewhere.

A. S. LaUghton

A. H. Stride

National Institute of Oceanography, Wormley,

Godalming, Surrey.

June 27.

${ }_{1}^{1}$ Rowe, A. W., Proc. Geol. Assoc., Lond., 18, 193 (1904).

¿ Bullard, E. C., Gaskell, T. F., Harland, W. B., and Kerr-Grant, C. Phil. Trans. Roy. Soc., A, 239, 476 (1946). Hill, M. N., and King, Phil. Trans. Roy. Soc., A, 239, 476 (1946) Hill, M. N.

'Bentz, A., and Closs, H., Proc. Fourth World Petroleum Congress, Rome, Seet. 1, 691 (1955).

\section{A Simple Method of determining Ultrasonic Velocities in Rocks}

WE have devised a simple method of determining elastic constants of rocks which is based on the principle of the critical angle method employed by Schneider and Burton'. In this method a narrow beam of ultrasonic waves strikes the rock section immersed in a liquid at right angles to its axis of rotation, and the critical angles $\theta_{d}$ and $\theta_{s}$ for total reflexion of the longitudinal and transverse waves set up in the section are determined experimentally. Knowing the velocity of ultrasonic waves $V$ in the liquid, the velocities of longitudinal and transverse velocities $V_{d}$ and $V_{s}$ in the rock section are determined by using the familiar relations,

$$
V_{d}=V / \sin \theta_{d} ; \quad V_{s}=V / \sin \theta_{s}
$$

The experimental arrangement consists of a $2 \frac{1}{2}$-in. brass ultrasonic cell having two holes of $\frac{7}{8} \mathrm{in}$. diameter on two opposite faces. Two identical silvered quartz $X$-cut plates of $1 \frac{1}{8}$ in. diameter and $1 \cdot 1 \mathrm{Mc} / \mathrm{sec}$. fundamental frequency are clamped against the holes from outside and serve as sender and receiver crystals. They are completely shielded by metal enclosures having provisions for making connexions to the crystals by shielded cables. One of the crystals which serves as the ultrasonic generator is connected to a completely shielded variable frequency oscillator giving a radio-frequency output of 150 volts while the other is connected across the input of a sensitive vacuum tube voltmeter. The silvered surfaces of the crystals which are kept pressed against the brass cell are at ground potential and serve effectively as shields preventing direct pick-up of the oscillator voltage by the voltmeter. The cell is filled with water or any other liquid and the oscillator is tuned to the fundamental frequency of the crystal by adjusting for maximum deflexion in the voltmeter. The rock

\begin{tabular}{|c|c|c|c|c|c|}
\hline Specimen & $\begin{array}{c}\text { Density } \\
\text { (gm./c.c.) }\end{array}$ & $\theta_{d}$ & 0. & $\begin{array}{c}V_{d} \\
(\mathrm{~m} . / \mathrm{s} .)\end{array}$ & $\underset{(\mathrm{m} . / \mathrm{s} .)}{V}$ \\
\hline $\begin{array}{l}\text { Khondalite } \\
\text { Schale } \\
\text { Baraker Sand- }\end{array}$ & $\begin{array}{l}2 \cdot 36 \\
2 \cdot 78\end{array}$ & $\begin{array}{ll}20^{\circ} & 0^{\prime} \\
15^{\circ} & 7^{\prime}\end{array}$ & $\begin{array}{l}50^{\circ} 24^{\prime} \\
50^{\circ} 5^{\prime}\end{array}$ & $\begin{array}{l}4,415 \\
5,790\end{array}$ & $\begin{array}{l}1,960 \\
1,970\end{array}$ \\
\hline $\begin{array}{l}\text { stone } \\
\text { Red ochre* } \\
\text { Talc chlorite }\end{array}$ & $\begin{array}{l}2 \cdot 66 \\
3 \cdot 52\end{array}$ & $\begin{array}{l}17^{\circ} 3^{\prime} \\
21^{\circ} 1^{\prime}\end{array}$ & $\begin{array}{l}50^{\circ} 5^{\prime} \\
48^{\circ} 4^{\prime}\end{array}$ & $\begin{array}{l}5,152 \\
4,166\end{array}$ & $\begin{array}{l}1,970 \\
2,034\end{array}$ \\
\hline $\begin{array}{l}\text { schist.* } \\
\text { Chalk* }{ }^{*} \\
\text { Kaolin* } \dagger\end{array}$ & $\begin{array}{l}2 \cdot 82 \\
1 \cdot 67 \\
1 \cdot 62\end{array}$ & $\begin{array}{l}14^{\circ} 11^{\prime} \\
17^{\circ} 38^{\prime} \\
17^{\circ} 0^{\prime}\end{array}$ & $\begin{array}{ll}47^{\circ} & 30^{\prime} \\
35^{\circ} & 40^{\prime} \\
33^{\circ} & 42^{\prime}\end{array}$ & $\begin{array}{l}6,156 \\
3,038 \\
3,115\end{array}$ & $\begin{array}{l}2,048 \\
1,577 \\
1,640\end{array}$ \\
\hline
\end{tabular}

* Coated with collodion. †'Tank liquid carbon tetrachloride.

section, which is in the form of a rectangular plate of approximate dimensions 2 in. $\times 1 \frac{1}{2}$ in. $\times 1 / 5$ in., is clamped to a slow-motion rotation arrangement having a gear reduction ratio of $50: 1$ and is immersed vertically in the liquid in the cell so that it intercepts the direct ultrasonic beam from the transmitter to the receiver. Each division of the vernier scale of the rotation arrangement corresponds to an angle of rotation of $4 \cdot 3^{\prime}$. A levelling arrangement is provided so as to adjust the axis of rotation of the section to be perpendicular to the direction of propagation of the ultra-sonic waves. By noting the four positions showing sharp dip in transmission energy on either side of normal incidence, the values of $\theta_{d}$ and $\theta_{s}$ are experimentally determined and the velocities are calculated in the usual manner. The method was first tested by determining velocities of sound propagation in some common metals. Sound velocities in some difficult ty pes of Indian rock materials, some of which are porous and water absorbing, were determined by this method after giving a coating of collodion film, and the values are presented in Table 1. Check measurements on glass and metal plates have shown that the values are not affected by the thin film of collodion.

Ultrasonic velocities for most of these rocks have not been determined before. It is interesting to note that in some of the materials like chalk and kaolin, for which transverse sound velocity is nearly as low as that of water, carbon tetrachloride has to be used as the tank liquid in order to ensure that the critical angle is not close to $90^{\circ}$.

The method presented here has the unique advantage, particularly for the determination of elastic constants of rocks, of being most simple, rapid and sufficiently accurate. There is no difficulty either in the preparation of the specimen as the thickness need not be uniform.

\section{K. Subbarao \\ B. Ramachandra RaO}

Ultrasonic Laboratories,

Physics Department,

Andhra University, Waltair.

May 13.

${ }^{1}$ Schneider, W. C., and Burton, C. J., J. App. Phys., 20, 48 (1949).

\section{Chemical Shifts in $\mathrm{C}_{5} \mathrm{H}_{5}-$ and $\mathrm{C}_{7} \mathrm{H}_{7}+$ lons : the Free Electron Model}

IN an earlier communication ${ }^{1}$, the classical free electron model proposed by Pople ${ }^{2}$ was modified and successfully applied to the description of the nuclear resonance spectra of hydrocarbons containing sixmembered aromatic rings. It was then noted that 